Article

\title{
Invasive Goldenrod (Solidago gigantea) Influences Soil Microbial Activities in Forest and Grassland Ecosystems in Central Europe
}

\author{
Lenka Bobul'ská ${ }^{1, *}$, Lenka Demková ${ }^{1}$, Andrea Čerevková $^{2}$ (1) and Marek Renčo ${ }^{2}$ \\ 1 Department of Ecology, Faculty of Humanities and Natural Sciences, University of Prešov, 17. novembra 1, \\ 08116 Prešov, Slovakia \\ 2 Institute of Parasitology, Slovak Academy of Science, Košice, Hlinkova 3, 04001 Košice, Slovakia \\ * Correspondence: bobulska.lenka@gmail.com; Tel.: +421-903-032-998
}

Received: 28 June 2019; Accepted: 12 August 2019; Published: 14 August 2019

check for updates

\begin{abstract}
A giant goldenrod plant, Solidago gigantea, native to North America is rapidly spreading in Europe and may have serious impact on ecosystems that inhabit. There is a lack of information about the effects of this species on soil biochemical properties and distribution and activity of microbial community. We analyzed soil physicochemical properties (soil reaction, soil moisture content, organic carbon and total nitrogen content) associated with activity of microbial population (activity of fluorescein diacetate (FDA), beta-glucosidase, urease and phosphatases enzymes) between invaded and adjacent uninvaded control sites in two habitats, forest and grassland, in the lowland of southeast Slovakia during years 2016 and 2017. The results revealed that invasion of S. gigantea significantly altered several soil properties and is associated with different soil properties. Soil acidity increased, organic carbon and moisture content decreased, while total nitrogen content was not significantly affected by invasion. FDA and urease activity were significantly higher in uninvaded sites. In contrast, beta-glucosidase and alkaline phosphatase activity were enhanced by S. gigantea invasion in both ecosystems studied. Acid phosphatase was not affected by the invasion. Our study proved that S. gigantea can influence several soil microbial properties while others remained unaffected, despite its significant impact on basal soil physicochemical properties.
\end{abstract}

Keywords: plant invasion; Solidago gigantea; biological indicators; soil properties

\section{Introduction}

Invasive (exotic) species have recently become a major concern of ecologists because of their threat to community composition and ecosystem quality and function changes. Recent studies have shown that invasive species may significantly alter soil properties, the composition of native vegetation, as well as microbial population in soil ecosystem. Plant invasiveness may alter nutrients cycles, such as carbon, nitrogen, and their mineralization, it significantly influences enzymatic and microbial activities in various soil ecosystems in the world [1,2]. To manage invasions and preserve ecosystems, we need to characterize the community- and ecosystem-level effects of introduce species and elucidate the traits that enable these species to have such effects [3]. Invasive (exotic) plants can change the diversity and functioning of soil microbial communities, alter soil food web structure and influence nutrient cycling [4]. It has been shown that exotic plants are successful not even in their natural habitat and alter soil properties (biota and nutrients) if they differ functionally from the native species [5]. Thus, invasion effects on soil conditions are likely to depend upon the dissimilarity between native and invading plant species [6]. These impacts result mainly in changes of soil organic matter (SOM) and soil microbial properties, such as soil microbial activity and soil microbial biomass [7]. SOM is a property 
that influences soil function and directly influence soil health and quality of the environment [8]. Transformation of organic carbon in soils has a direct link to soil microbial attributes and some authors confirm that invasion has a positive effect on content of organic pool in soil ecosystems [9,10], the others showed the loss of organic matter in the specific valuable ecosystems [11,12]. Soil microbial community plays a key role in soil processes and soil enzymes catalyse reactions in soil system that have biochemical significance. Soil enzymes participate in nutrient cycles, such as carbon (beta-glucosidase), nitrogen (urease) and phosphorus (phosphatases). These enzymes transfer energy through organic matter decomposition and nutrients are released to be available for plant growth. Besides the activity of soil enzymes, other indices may be considered as the indicators of microbial activity, such as soil microbial biomass carbon, soil respiration or fluorescein diacetate activity (FDA). All these referred parameters are more sensitive in assessing changes in soil use and management $[7,13]$ and such indicators are important for assessing the intensity of soil degradation, as well as extension of plant invasion in soil ecosystems [14].

The giant goldenrod, Solidago gigantea Ait. (Asteraceae) is a North America plant species in the sunflower family that has spread in a number of European and Asian countries after introduction as an ornamental plant. The main period for new rhizome growth relevant to flowering shoots in Slovakia is September (or late August) and is unintentionally spread and commonly found in abandoned farmlands, roadsides, gardens, forests, orchards, and even green spaces of some cities [15,16]. Its harmful impact to environment has been shown in several studies that focused on soil nutrient cycling and microbial functional diversity [17], plant diversity [16] and trophic structure of insect-associated communities $[18,19]$. To gain insight into the mechanisms of Solidago genus, numerous studies have been focused on aboveground communities in nonnative areas. These studies have also focused on morphological evaluation of Solidago genus in introduced areas [20], its physiological adaptation to diverse environments [21] and evaluation of its phytoremediation properties in loaded areas in Slovakia [22]. Although these studies shed light on the plant ecological mechanisms of Solidago genus invasion in nonnative areas, relatively little is known about the effect of $S$. gigantea invasion on activity of soil microbial population [23].

We performed biennial investigation based on 40 independent study sites to assess the impact of S. gigantea invasion on soil physicochemical properties and the activity of soil microbial communities. The aim of the study was to (i) determine the selected physicochemical properties and biological indices and (ii) evaluate the impact of invasive species $S$. gigantea on soil properties and enzymatic activity. It was hypothesized that microbial activity would differ both between invasive and native species, as well as between ecosystems where invasion takes place. Microbial activity would be related to the physicochemical soil properties. The weaker effect on soil would be in the grasslands due to higher understory native plant diversity that can inhibit the impact of S. gigantea.

\section{Materials and Methods}

\subsection{Study Site and Soil Sampling}

The study was carried out in cadastre of Košice Basin in the lowland of southeast Slovakia $\left(48^{\circ} 42^{\prime} \mathrm{N} 21^{\circ} 18^{\prime} \mathrm{E}\right.$, Figure 1). Climate in this region is warm and in winter season temperatures range from -1 to $-3{ }^{\circ} \mathrm{C}$, in summer season between 18 and $20^{\circ} \mathrm{C}$. Snow covers less 50 days, the number of summer days is 60 to 70 and an annual precipitation is $600 \mathrm{~mm}$. The soil was classified as Halpic Cambisols. The study sites were located within an area of $20 \mathrm{~km} \times 15 \mathrm{~km}$, with mean distance of $3.5 \mathrm{~km}$ between each other. Elevation of the study sites ranged from 192 to $380 \mathrm{~m}$ a.s.l. The invaded plot was required to have a cover of $S$. gigantea of at least $80 \%$, while the control sites were adjacent uninvaded plots with no invasive species. The mean distance between the invaded and uninvaded sites was $200 \mathrm{~m}$. The uninvaded sites were assumed to represent sites prior to invasion by this species. Pairs of invaded and uninvaded areas did not differ in elevation, inclination, exposition, type and management. The samples were taken from two different habitats: the forest and grassland ecosystems 
with no obvious differences in topography, or soil characteristics. Grassland and forest ecosystems were predominantly chosen because the abundance and diversity of the invasive species is easily spreading in these types of ecosystems and extrude native species. No management (mowing and grazing) was performed at the research sites. Control sites (especially grassland) was mainly located close to the arable land and ruderal areas which might directly influence the composition of plant communities. Description of the vegetation was done for the dominated species occurred at the moment of soil sampling.
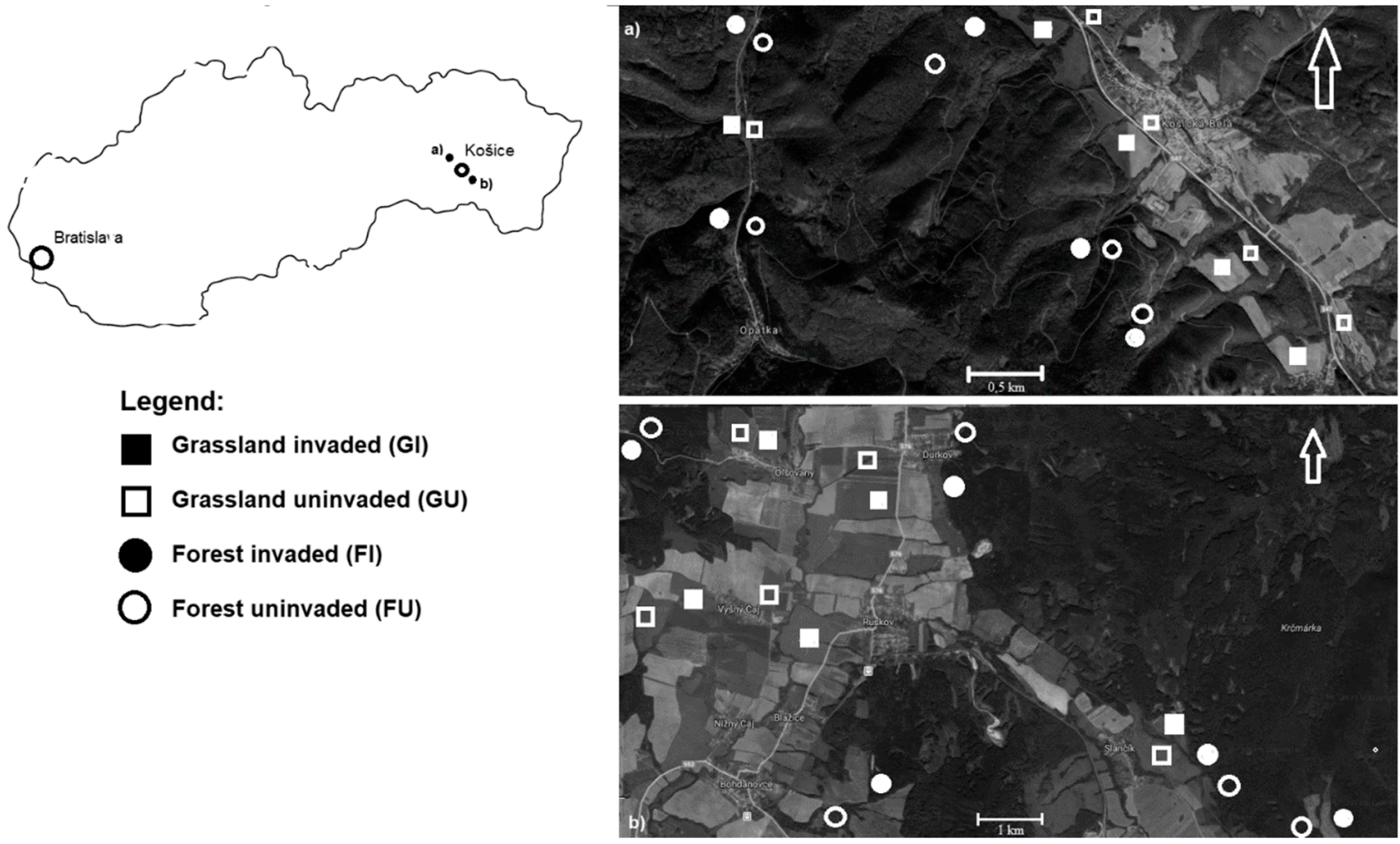

Figure 1. Experimental localities and sampling points of the studied area in Košice Basin.

Characteristic of individual sites were as follows:

Forest Uninvaded (FU): Ten study sites were located in stands dominated by Quercus sp., Fagus sp., Carpinus sp. and Betula sp. (deciduous forests).

Grassland Uninvaded (GU): Ten study sites with indigenous multispecies vegetation dominated by Dactylis glomerata, Lolium perenne, Trifolium pratense, Capsella bursa-pastoris and Taraxacum officinale.

Forest Invaded (FI): Ten adjacent study sites with monospecific stand of S. gigantea on forest edge, with an estimated time of invasion of 10-15 years.

Grassland Invaded (GI): Ten adjacent study sites invaded by S. gigantea, with an estimated time of invasion of 10-20 years.

Soil samples were collected twice, in September 2016 and 2017 from all study sites. In each invaded site, ten randomly chosen $1 \mathrm{~m} \times 1 \mathrm{~m}$ plots were chosen. Similarly, ten $1 \mathrm{~m} \times 1 \mathrm{~m}$ plots with an equal spatial distribution were chosen in the corresponding uninvaded sites. At each plot a mixed soil samples consisted of five subsamples in the depth of $0.1-0.2 \mathrm{~m}$. All soil samples were transferred to the laboratory in plastic bags and homogenized manually before analyzing.

\subsection{Soil Physicochemical Analysis and Enzyme Assays}

Air-dried soil samples were used to measure soil $\mathrm{pH}$, organic carbon and total nitrogen content. Gravimetric soil moisture was calculated on $10 \mathrm{~g}$ of fresh subsamples after drying in a $105^{\circ} \mathrm{C}$ oven for $24 \mathrm{~h}$. Soil $\mathrm{pH}$ was detected in a 1:3 mixture of soil and $0.01 \mathrm{M} \mathrm{CaCl}_{2}$ solution using a digital $\mathrm{pH}$ meter. 
Soil organic carbon was determined by the Turin's method and total nitrogen carbon using Kjeldahl method [24].

Enzymatic activity assays were determined using field-moist soil samples, which were sieved through a 2-mm sieve and properly homogenized. Each enzyme assay was performed as described in Table 1 [25-28]. Determination of physicochemical properties and enzymes were analysed in triplicate. For each soil enzyme activity, the corresponding control was performed by the same analysis, but without the addition of the substrate. Activity of all enzymes was measured in a spectrophotometer creating a reference curve.

Table 1. Incubation condition of enzymes used with biochemical indicators.

\begin{tabular}{|c|c|c|c|c|c|c|}
\hline \multirow{2}{*}{ Enzyme } & \multicolumn{5}{|c|}{ Incubation Condition } & \multirow{2}{*}{ Reference } \\
\hline & Substrate & Buffer (pH) & Temperature $\left({ }^{\circ} \mathrm{C}\right)$ & Soil (g) & Time (h) & \\
\hline BGL & $\begin{array}{c}\text { 4-Nitrophenyl } \\
\text { glucopyranoside }\end{array}$ & MUB (6.0) & 37 & 1 & 3 & [25] \\
\hline FDA & Fluorescein diacetate & PPB (7.6) & 30 & 1 & 1 & [26] \\
\hline $\mathrm{PHOS}_{\mathrm{AL}}$ & p-Nitrophenyl phosphate & $\mathrm{AB}(5.0)$ & 37 & 5 & 3 & [27] \\
\hline PHOS $_{\mathrm{AC}}$ & p-Nitrophenyl phosphate & BB (10.0) & 37 & 5 & 3 & [27] \\
\hline URE & Urea & PB (6.7) & 37 & 5 & 24 & [28] \\
\hline
\end{tabular}

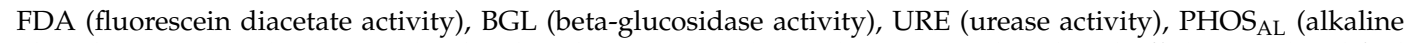
phosphatase activity), PHOS $_{\mathrm{AC}}$ (acidic phosphatase activity), $\mathrm{PPB}$ (potassium phosphate buffer), MUB (modified universal buffer), $\mathrm{AB}$ (acetate buffer), BB (borate buffer).

\subsection{Statistical Analyses}

All statistical operations were performed in R studio program [29]. Normality of the data was verified by the Shapiro-Wilk test. Spearman's correlation coefficient was used to detect relationships between soil properties and characteristics of soil microbial activity. The Mann-Whitney nonparametrical test was used to determine significant differences in soil properties between ecosystems (forest, grassland) and between the invasion status (invaded, noninvaded sites) of evaluated locality.

\section{Results}

\subsection{Soil Physicochemical Properties}

Physical and chemical properties of soils from two ecosystems (forest and grassland) that present invaded and uninvaded systems are shown in Figure 2. The areas are within the same edaphoclimatic conditions and have the same soil textural classes and Cambisol soil type.

Soil reaction was significantly higher in the grassland ecosystem compared to the forest during the research period (Table 2). The results also revealed that invasive Goldenrod is able to increase the value of $\mathrm{pH}$ in both ecosystems, but this relation was statistically observed only in the forest ecosystem (Table 3). The exception was only recorded in the grassland ecosystem in 2016, where soil pH slightly decreased. According to soil $\mathrm{pH}$, the grassland ecosystem is represented by slightly acidic to neutral soil (6.0-7.2), the forest ecosystem represents soil heavy acidic to acidic (4.5-5.7). Content of soil moisture was statistically lower in invaded ecosystems compared to the control in both years of our study (Table 3). Organic carbon content was generally greater in uninvaded ecosystems and the higher portion of organic carbon was shown in grassland ecosystems than in forest systems (Table 2). In both ecosystems, the content of organic carbon showed moderate to very high concentration of the values $(1.4 \%-4.3 \%)$. Total nitrogen concentration was also greater in uninvaded ecosystems with the higher portion in grassland system, but these differences were not large enough to be significant. Soil physical and chemical properties significantly varied between the years 2016 and 2017, but soil reaction and soil moisture were the only parameters that have not changed in forest ecosystem (Figure 2). 

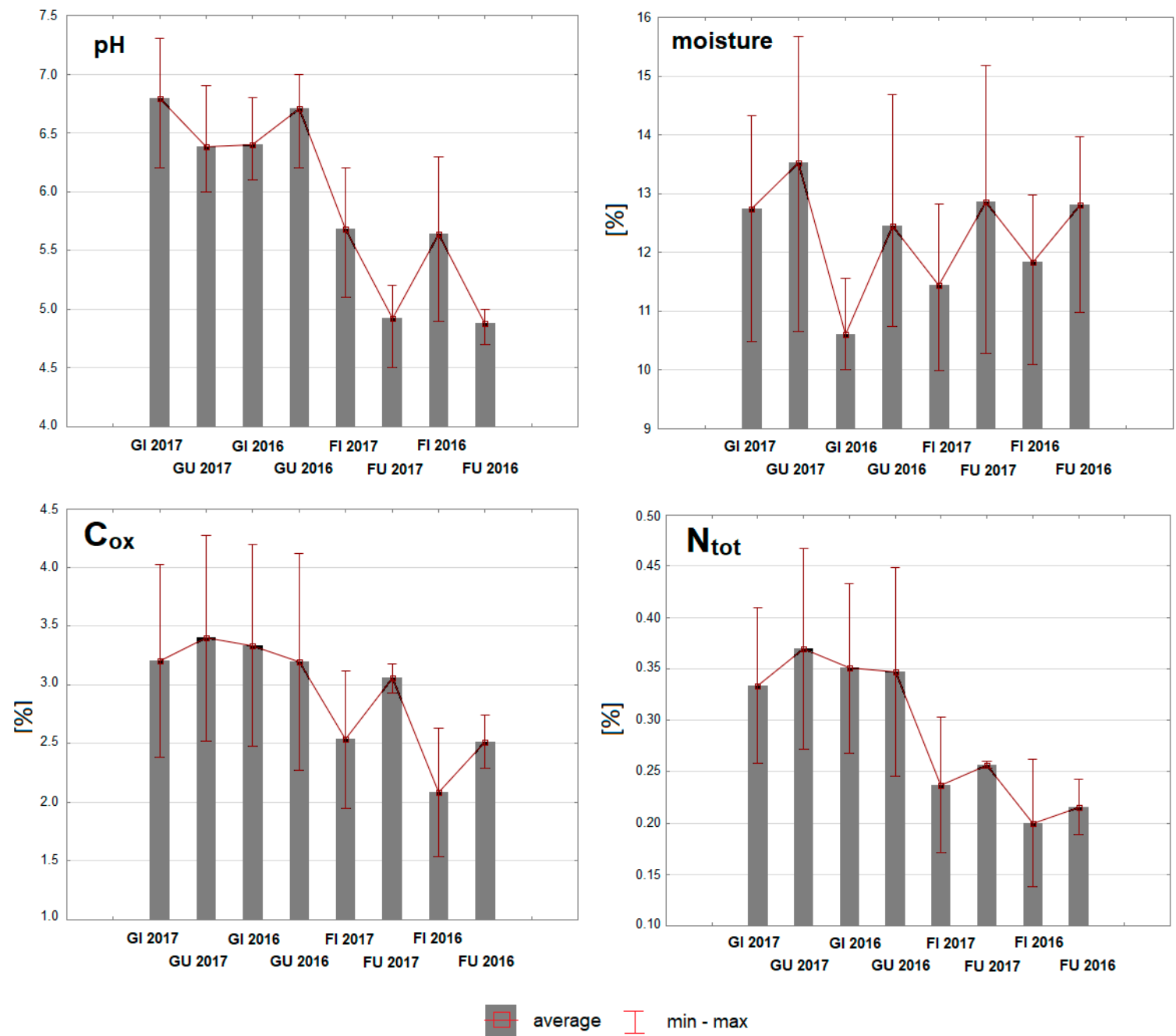

Figure 2. Soil physicochemical properties in two ecosystems (forest and grassland) under invaded and uninvaded sites in 2016 and 2017 ( $\mathrm{pH}$ (in 0.01M CaCl 2 ), moisture (soil moisture \%), $\mathrm{C}_{\text {ox }}$ (soil organic carbon \%), $\mathrm{N}_{\text {tot }}$ (total nitrogen \%), FI (forest invaded ecosystem), FU (forest uninvaded ecosystem), GI (grassland invaded ecosystem), GU (grassland uninvaded ecosystem).

Table 2. The values of Mann-Whitney nonparametrical test for comparison soil characteristics between ecosystems (grassland and forest) regardless of the year and the invasion status (invaded, noninvaded sites).

\begin{tabular}{|c|c|c|c|c|}
\hline Parameter & & $\bar{U}$ & $\bar{z}$ & $p$ Value \\
\hline $\mathrm{pH}$ & & 49.5 & -7.2 & 0.0001 * \\
\hline MOIS & & 798 & -0.1 & 0.98 \\
\hline Cox & & 525 & -2.64 & 0.008 * \\
\hline Ntot & & 225 & -5.52 & 0.0001 \\
\hline BGL & $\begin{array}{l}\text { Between } \\
\text { ecosvstems }\end{array}$ & 659 & 1.34 & 0.17 \\
\hline FDA & ecosystems & 624 & 1.68 & $0.05 *$ \\
\hline URE & & 717 & 0.79 & 0.42 \\
\hline PHOS $_{\mathrm{AC}}$ & & 544 & 2.45 & $0.01 *$ \\
\hline $\mathrm{PHOS}_{\mathrm{AL}}$ & & 248 & -5.8 & $0.0001^{*}$ \\
\hline
\end{tabular}

MOIS (soil moisture), Cox (soil organic carbon), Ntot (total nitrogen), FDA (fluorescein diacetate activity), BGL (beta-glucosidase activity), URE (urease activity), PHOSAL (alkaline phosphatase activity), PHOSAC (acidic phosphatase activity), ${ }^{*} p<0.05$. 
Table 3. The values of Mann-Whitney nonparametrical test for comparison soil characteristics between invaded and uninvaded sites in grassland $(\mathrm{G})$ and forest $(\mathrm{F})$ ecosystem, regardless of the year.

\begin{tabular}{|c|c|c|c|c|c|c|c|}
\hline \multirow{2}{*}{ Parameter } & & \multicolumn{3}{|c|}{ F } & \multicolumn{3}{|c|}{ G } \\
\hline & & $\mathbf{U}$ & $\mathrm{z}$ & $p$ Value & $\mathrm{U}$ & $\mathrm{z}$ & $p$ Value \\
\hline $\mathrm{pH}$ & & 30 & 4.58 & 0.0001 * & 190 & 0.25 & 0.79 \\
\hline MOIS & & 103 & -2.61 & $0.009 *$ & 102 & -2.63 & $0.008 *$ \\
\hline $\mathrm{C}_{\mathrm{ox}}$ & & 100 & -2.69 & $0.007 *$ & 175 & -0.66 & 0.50 \\
\hline $\mathrm{N}_{\text {tot }}$ & Between & 200 & 0.02 & 1.0 & 150 & -1.33 & 0.18 \\
\hline BGL & invaded and & 68 & 3.55 & $0.001 *$ & 96 & 2.79 & 0.005 * \\
\hline FDA & uninvaded sides & 186 & -3.6 & 0.71 & 64 & -3.66 & 0.0002 * \\
\hline URE & & 55 & -3.9 & $0.0001 *$ & 105 & -2.54 & $0.01 *$ \\
\hline $\mathrm{PHOS}_{\mathrm{AC}}$ & & 161 & -1.04 & 0.29 & 190 & -0.25 & 0.79 \\
\hline $\mathrm{PHOS}_{\mathrm{AL}}$ & & 90 & 2.96 & $0.003 *$ & 95 & 2.85 & 0.004 * \\
\hline
\end{tabular}

MOIS (soil moisture), Cox (soil organic carbon), Ntot (total nitrogen), FDA (fluorescein diacetate activity), BGL (beta-glucosidase activity), URE (urease activity), PHOSAL (alkaline phosphatase activity), PHOSAC (acidic phosphatase activity), * $p<0.05$.

\subsection{Microbial Indicators and Enzyme Assays}

Microbial indicator that was represented by FDA activity was variable parameter and S. gigantea decreased activity of soil in both invaded ecosystems in 2017 compared to uninvaded, but a year earlier this effect was no evident in forest ecosystem. Some enzyme activities (alkaline phosphatase, urease and beta-glucosidase) significantly varied between the years 2016 and 2017 (Figure 3). On the other hand, more stable parameters in both ecosystems seem to be the activity of FDA and acid phosphatase, in that the values did not significantly change during the research period. The activity of all microbial parameters in invaded and uninvaded sites are graphically described in Figure 3.

Beta-glucosidase activity was significantly greater in invaded sites compared to uninvaded sites and the same trend was also observed for alkaline phosphatase. The opposite trend was detected for activity of soil urease, where its value significantly decreased in invaded sites compared to uninvaded (Table 3). Activity of acid phosphatase was slightly lower in invaded sites, except in forest ecosystem in 2016 where this trend was opposite, but this relationship was not statistically shown.

\subsection{Correlation Analysis of Soil Characteristics between Ecosystem Invasive Status and Microbial Parameters} with Environmental Variables

The effects of $S$. gigantea on abiotic and biotic soil properties were generally significantly different between the invaded and uninvaded sites (Table 4). Nonsignificant interaction was only found for total nitrogen concentration and activity of acid phosphatase. Significant differences were also found between two researched ecosystems (forest and grassland) for some variables (soil reaction, content of organic carbon, FDA and phosphatases activities) regardless of the year of the study and invasion status of studied ecosystems. The type of ecosystem did not affect the soil moisture, total nitrogen and activity of beta-glucosidase and urease (Table 2). 

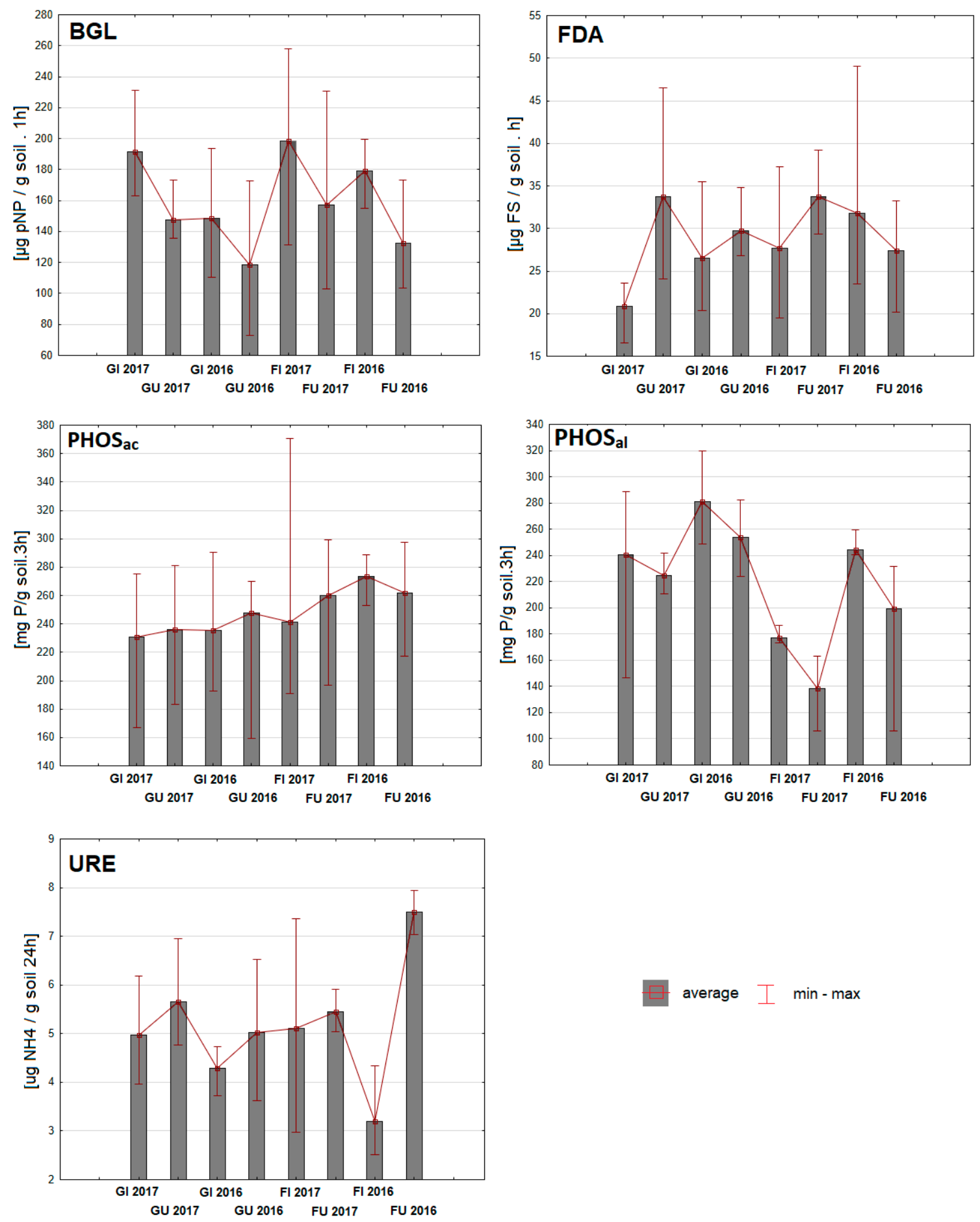

average $I \min -\max$

Figure 3. Soil microbial indicators in two ecosystems (forest and grassland) under invaded and uninvaded sites in 2016 and 2017 (FDA (fluorescein diacetate activity), BGL (beta-glucosidase activity), URE (urease activity), PHOS $_{\mathrm{al}}$ (alkaline phosphatase activity), PHOS $_{\mathrm{ac}}$ (acidic phosphatase activity), FI (forest invaded ecosystem), FU (forest uninvaded ecosystem), GI (grassland invaded ecosystem), GU (grassland uninvaded ecosystem)). 
Table 4. Correlation relationship between analysed soil characteristics (regardless the year of study, ecosystem and invasion status).

\begin{tabular}{cccccccccc}
\hline Parameter & $\mathbf{p H}$ & MOIST & $\mathbf{C}_{\mathbf{~ o x}}$ & $\mathbf{N}_{\text {tot }}$ & $\mathbf{B L G}$ & $\mathbf{F D A}$ & URE & PHOS $_{\mathrm{AC}}$ & PHOS $_{\mathrm{AL}}$ \\
\hline $\mathrm{pH}$ & -0.08 & -0.07 & $0.30^{* *}$ & $0.51^{* *}$ & -0.01 & $-0.28^{*}$ & -0.39 & $-0.31^{*}$ & 0.59 \\
$\mathrm{MOIS}$ & & & $0.38^{* *}$ & $0.35^{* *}$ & 0.16 & $0.55^{* *}$ & 0.05 & $0.23^{*}$ & -0.22 \\
$\mathrm{C}_{\mathrm{ox}}$ & & & & $0.96^{* *}$ & 0.17 & 0.21 & -0.11 & 0.17 & -0.06 \\
$\mathrm{~N}_{\text {tot }}$ & & & & & 0.14 & 0.17 & -0.18 & 0.11 & 0.17 \\
BGL & & & & & & 0.12 & $-0.31^{* *}$ & 0.12 & -0.14 \\
FDA & & & & & & & -0.05 & 0.21 & -0.20 \\
URE & & & & & & & & 0.08 & $-0.33^{* *}$ \\
PHOS $_{\text {AC }}$ & & & & & & & & -0.13 \\
\hline
\end{tabular}

MOIS (soil moisture), Cox (soil organic carbon), Ntot (total nitrogen), FDA (fluorescein diacetate activity), BGL (beta-glucosidase activity), URE (urease activity), PHOSAL (alkaline phosphatase activity), PHOSAC (acidic phosphatase activity), ${ }^{*}, * * p<0.05,0.01$.

\section{Discussion}

\subsection{Soil Physicochemical Properties}

Changes in soil physicochemical and biological properties that are altered by plants can play an important role for the invasion success of exotic plant species [30]. However, the impact of exotic plants on given physical and chemical soil indices can vary widely [31]. Invasion of two different ecosystems in Slovakia by S. gigantea is accompanied by the effect of ecosystem functioning and type of ecosystem. This species reduced the content of organic matter and except concentration of total nitrogen, all physicochemical parameters were significantly changed by invasiveness.

In addition, invasion by this species can also generate changes in the activity of soil microbial indices, which may influence the composition of native plants and diversity of soil fauna as was described by some authors $[18,32]$. In this study, we detected a previously described study about how S. gigantea can influence some parameters, mainly focused on soil enzyme activities. Plant invasion has been previously found to alter nutrient cycling due to changes produced in the quality and quantity of soil organic matter [1]. Exotic plants can form dense covers, have intensive and fast growth rate and produce large amounts of litter [33]. The influence of invasive species on the organic matter cycle has been reported previously, but this influence can be positive or negative [34]. Some authors state that this characteristic of invasive species can increase soil moisture and organic carbon [35,36], but our study revealed the opposite trend which was also correlated with studies by Feng et al. [9]. Some ecosystems (forest systems especially) worldwide are able to storage carbon in soil that involves numerous components including biomass carbon and soil carbon [37] and every ecosystem stress (pollution, invasive status, etc.) might lead to degradation and diversity changing in soil system [38]. This could explain the lower organic carbon and soil moisture content observed at the invaded sites compared to uninvaded. Furthermore, S. gigantea appeared to reduce soil moisture. Moisture may limit activity of microbial population in a wide range of environments including soils, and low water availability can reduce its activity by lowering intracellular water potential and thus reducing hydration and activity of enzymes [39]. Lower soil moisture content at the invaded sites during the research period was probably due to more biomass of invasive species that can also strongly influence more physical properties as describe works of Rusterholz et al. [31] and Stefanowicz et al. [40], which was also shown in our study. Soil $\mathrm{pH}$ is one of the important factors of soil quality despite the facts that it changes dynamically depending on the so-called internal and external factors [41]. Grassland soils tends to be less acidic compared to forest soils [37] that we also observed. There are many authors that describe how exotic plants and especially how Goldenrod affects physical properties. Some authors reported that invasion of S. gigantea significantly increase soil reaction [16,42], but the work of Quist et al. [43] showed the opposite trend: that S. gigantea can lower the $\mathrm{pH}$ in a soil system they had invaded. 


\subsection{FDA and Soil Enzymes Activity}

Many authors have focused their research on population ecology, impact on some physicochemical indices in soil, or physiological adaptation of the Solidago genus in the environment $[6,16,18,19,21,40]$, but there is a lack of information as to how biological properties (especially enzyme activities) are altered by this species invasion. In this study, we used the hydrolysis of fluorescein diacetate (FDA) to assess the total microbial activity. FDA is a good general measure of organic carbon turnover in natural ecosystem because most energy flow passes through decomposition of microbial community and several enzyme activities are also involved in this process [44]. The analysis of FDA in our study suggests that the plant invasion in our study in both ecosystems decreased the soil microbial activity. The work of Chacón et al. [45] presented that S. gigantea increased the activity of FDA; the work of Sicardi et al. [46] that corresponded with our study showed that activity of enzymes was decreased by invasion of this exotic species.

There are a number of enzymes in soil, depending on diversity and abundance of soil organisms and conditions of organic substances turnover. The activity of biological indices in soil ecosystems may be influenced by several factors, both natural and anthropogenic [13]. Increased soil acidity inhibits the activity of beneficial bacteria and thus reduces the activity of the soil ecosystems [41]. In our study, the strong correlation with soil reaction was also found with some indices of microbial activity (FDA and acid phosphatase). Overall, Scharfy et al. [6] showed that S. gigantea reduces bacterial biomass and therefore alters the activity of many soil enzymes.

Activity of beta-glucosidase is an important enzyme in the soil carbon cycle and might be considered as a potential microbial parameter, indicating the stress and disturbance of the soil ecosystem [47]. Our study revealed significant decrease of this enzyme in invaded sites which also correspond with several studies [48,49].

Soil reaction differs from the $\mathrm{pH}$ optimum for phosphatases activity. Activity of these enzymes is higher in soils with higher humidity than in drier soils or soils with normal humidity [50], which also corresponds with our study, where the correlation between soil moisture and acid phosphatase is shown. Phosphatases have a different optimal $\mathrm{pH}$ and are therefore divided into acid and alkaline. Our study also showed that in more acidic conditions that represents forest ecosystem, the content of acid phosphatase is higher compared to the grassland ecosystem. The study also revealed that S. gigantea significantly increased the activity of alkaline phosphatase, but the activity of acid phosphatase was not affected, which also corresponds with the work of Chacón et al. [45], suggesting that invasive plants are not phosphorus-limited.

One of the most common enzymes in microbial, animal and plant cells is urease. In many studies, urease activity is correlated to soil organic carbon due to the stimulating effects of soil organic matter on soil microbial biomass and the stabilization of the extracellular urease by humic substances [51]. S. gigantea significantly decreased the activity of this enzyme, which was also shown in the work of Ge at al. [52].

It can be expected that the substitution of the native species by invaders leads to change in the composition and activity of microbial community. Work of Nannipieri et al. [44] showed that transformation of organic carbon was influenced by activity of soil enzymes, which provide the general information of microbial activity in soil environment. In the study of Kourtev et al. [53], it was found that some exotic plants were able to significantly increase the value of soil enzymes compared to the soil samples collected under the native plants; the other study of Sicardi et al. [46] showed that the introduction of invaders decreased activity of soil enzymes. Changes in physical and chemical properties could modify some soil biological parameters, such as microbial biomass, respiration rate, $\mathrm{N}$ mineralization, as well as concentration of soil enzymes [35]. According to our study, the significant correlation was also found among soil variables (Table 4), which was also shown in our previous works $[13,54]$. Because the control sites did not reveal the visible occurrence of individual species of exotic plants, the invadability of these habitats might be expected. It is not excluded that control 
sites do not present any seeds of invaders, therefore there is a limitation of this study and further investigation and monitoring of the sites are needed.

\section{Conclusions}

The activity of soil microbial population mainly represented by soil enzymatic content plays an important role in soil functioning and depends on environmental changes in the natural ecosystems. Invasion by $S$. gigantea in the studied area generated a soil environment that might significantly alter several soil physicochemical and microbial indices, and invasion is associated with different soil properties. Our results suggest that the activity of soil enzymes, as well as physicochemical properties, respond to soil composition changes represented by invasion of exotic goldenrod species. Therefore, all these parameters might be widely used as an indicator of environmental changes and natural disturbances. Of special note, the activity of soil enzymes has been reported as useful soil quality indicators because enzymes respond very quickly to soil management changes before other indicators changes are detectable. Moreover, soil enzymes are often closely related to physicochemical properties, microbial activity and biomass in soil systems, and can be an integrative soil biological index of past soil management.

Author Contributions: Conceptualization: M.R. and L.B.; Investigation and data collection: L.B., L.D., A.Č., M.R.; Data analysis: L.B., L.D.; Methodology: L.B., A.Č., M.R.; Resources: M.R., L.D.; Writing - original draft: L.B.

Funding: This research was supported by the project of Slovak Scientific Agency VEGA (Grant No. 2/0013/16) and Grant agency University of Prešov (GaPU 19/2019).

Conflicts of Interest: The authors declare no conflict of interest.

\section{References}

1. Herrera, I.; Ferrer-Paris, J.R.; Benzo, D.; Flores, S.; García, B.; Nassar, J.M. An invasive succulent plant (Kalanchoe daigremontiana) influences soil carbon and nitrogen mineralization in a neotropical semiarid zone. Pedosphere 2018, 28, 632-643. [CrossRef]

2. Kourtev, P.S.; Ehrenfeld, J.G.; Häggblom, M. Exotic plant species alter the microbial community structure and function in the soil. Ecology 2002, 83, 3152-3166. [CrossRef]

3. Aguilera, A.G.; Alpert, P.; Dukes, J.S.; Harrington, R. Impact of the invasive plant Fallopia japonica (Houtt.) on plant communities and ecosystem processes. Biol. Invasions 2010, 12, 1243-1252. [CrossRef]

4. Peltzer, D.A.; Bellingham, P.J.; Kurokawa, H.; Walker, L.R.; Wardle, D.A.; Yeates, G.W. Punching above their weight: Low-biomass non-native plant species alter soil properties during primary succession. Oikos 2009, 118, 1001-1014. [CrossRef]

5. Moles, A.T.; Gruber, M.A.M.; Bonser, S.P. A new framework for predicting invasive plant species. J. Ecol. 2008, 96, 13-17. [CrossRef]

6. Scharfy, D.; Güsewell, S.; Gessner, M.O.; Venterink, H.O. Invasion of Solidago gigantea in contrasting experimental plant communities: Effects on soil microbes, nutrients and plant-soil feedbacks. J. Ecol. 2010, 98, 1379-1388. [CrossRef]

7. Vinhal-Freitas, I.C.; Corrêa, G.F.; Wendling, B.; Bobul'ská, L.; Ferreira, A.S. Soil textural class plays a major role in evaluating the effects of land use on soil quality indicators. Ecol. Indic. 2017, 74, 182-190. [CrossRef]

8. Batlle-Bayer, L.; Batjes, N.H.; Bindraban, P.S. Changes in organic carbon stocks upon land conversion in the Brazilian Cerrado: A review. Agric. Ecosyst. Environ. 2010, 137, 47-58. [CrossRef]

9. Feng, J.; Wang, S.; Wang, S.; Ying, R.; Yin, F.; Jiang, L.; Li, Z. Effects of invasive Spartina alternifolia Loisel. and subsequent ecological replacement by Sonneratia apetala Buch.-Ham. on soil organic carbon fraction and stock. Forests 2019, 10, 171. [CrossRef]

10. Zhang, Y.; Ding, W.; Luo, J.; Donnison, A. Changes in soil organic carbon dynamics in an Eastern Chinese coastal wetland following invasion by a C4 plant Spartina alterniflora. Soil Biol. Biochem. 2010, 42, 1712-1720. [CrossRef] 
11. McGranahan, D.A.; Daigh, A.L.; Veenstra, J.J.; Engle, D.M.; Miller, J.R.; Debinski, D.M. Connecting soil organic carbon and root biomass with land-use and vegetation in temperate grassland. Sci. World J. 2014, 1, 487563. [CrossRef] [PubMed]

12. Wang, W.; Sardans, J.; Wang, C.; Zeng, C.; Tong, C.; Chen, G.; Huang, J.; Pan, H.; Peguero, G.; Vallicrosa, H.; et al. The response of stock of $\mathrm{C}, \mathrm{N}$, and $\mathrm{P}$ to plant invasion in the coastal wetlands of China. Glob. Chang. Biol. 2019, 25, 733-743. [CrossRef] [PubMed]

13. Bobul'ská, L.; Fazekašová, D.; Angelovičová, L.; Kotorová, D. Impact of ecological and conventional farming systems on chemical and biological soil quality indices in a cold mountain climate in Slovakia. Biol. Agric. Hortic. 2015, 31, 205-218. [CrossRef]

14. Constán-Nava, S.; Soliveres, S.; Torices, R.; Serra, L.; Bonet, A. Direct and indirect effects of invasion by the alien tree Ailanthus altissima on riparian plant communities and ecosystem multifunctionality. Biol. Invasions 2015, 17, 1095-1108. [CrossRef]

15. Pauková, Ž. Invasive plant species in the three microregions of Nitra region, South-West Slovakia. Ekológia Bratisl. 2013, 32, 262-266. [CrossRef]

16. Zhang, C.B.; Wang, J.; Qian, B.Y.; Li, W.H. Effects of the invader Solidago canadensis on soil properties. Appl. Soil Ecol. 2009, 43, 163-169. [CrossRef]

17. Pimentel, D.; McNair, S.; Janecka, J.; Wightman, J.; Simmonds, C.; O'Connell, C.; Wong, E.; Russel, L.; Zern, J.; Aquino, T.; et al. Economic and environmental threats of alien plant, animal, and microbe invasions. Agric. Ecosyst. Environ. 2001, 84, 1-20. [CrossRef]

18. Baranová, B.; Manko, P.; Jászay, T. Differences in surface-dwelling beetles of grasslands invaded and non-invaded by goldenrods (Solidago canadensis, S. gigantea) with special reference to Carabidae. J. Insect Conserv. 2014, 18, 623-635. [CrossRef]

19. Roháčová, M.; Drozd, P. How many heteropteran species can live on alien goldenrods Solidago canadensis and S. gigantea in Europe? Biologia 2009, 64, 981-993. [CrossRef]

20. Jakobs, G.; Weber, E.; Edwards, P.J. Introduced plants of the invasive Solidago gigantea (Asteraceae) are larger and grow denser than conspecifics in the native range. Divers. Distrib. 2004, 10, 11-19. [CrossRef]

21. Guo, S.L.; Fang, F. Physiological adaptation of the invasive plant Solidago canadensis to environments. Acta Physiol. Sin. 2003, 27, 47-52.

22. Bobul'ská, L.; Čekanová, K.; Demková, L.; Oboňa, J.; Sarvaš, J. Evaluation of the phytoremediation properties of the invasive species Solidago genus. Ann. Univ. Craiova 2018, 23, 314-320.

23. Stefanowicz, A.M.; Stanek, M.; Nobis, M.; Zubek, S. Species-specific effects of plant invasions on activity, biomass, and composition of soil microbial communities. Biol. Fertil. Soils 2016, 52, 841-852. [CrossRef]

24. Fiala, K.; Barančikova, G.; Brečkova, V.; Burik, V.; Houškova, B.; Chomaničova, A.; Kobza, J.; Litavec, T.; Makovnikova, L.; Pechova, B.; et al. Partial Monitoring System-Soil. Binding Methods, 1st ed.; VÚPOP: Bratislava, Slovakia, 1999; 139p.

25. Eivazi, F.; Tabatabai, M.A. Glucosidases and galactosidases in soils. Soil Biol. Biochem. 1988, 20, 601-606. [CrossRef]

26. Green, V.S.; Stott, D.E.; Diack, M. Assay for fluorescein diacetate hydrolytic activity: Optimization for soil samples. Soil Biol. Biochem. 2006, 38, 693-701. [CrossRef]

27. Grejtovský, A. Influence of soil improvers on enzymatic activity of heavy alluvial soil. Plant Soil Environ. 1991, 37, 289-295.

28. Khaziev, F.K. Soil Enzyme Activity, 1st ed.; Nauka: Moscow, Russia, 1976; 180p.

29. R Core Team. R: A Language and Environment for Statistical Computing, 1st ed.; R Foundation for Statistical Computing: Vienna, Austria, 2018; Available online: https://www.R-project.org/ (accessed on 22 February 2019).

30. Van der Putter, W.H.; Klironomos, J.N.; Wardle, D.A. Microbial ecology of biological invasions. ISME 2007, 1, 28-37. [CrossRef] [PubMed]

31. Rusterholz, H.P.; Schneuwly, J.; Baur, B. Invasion of the alien shrub Prunus laurocerasus in suburban deciduous forests: Effects on native vegetation and soil properties. Acta Oecol. 2018, 92, 44-51. [CrossRef]

32. Richard, M.; Tallamy, D.W.; Mitchell, A.B. Introduced plants reduce species interactions. Biol. Invasions 2019, 21, 983-992. [CrossRef]

33. Metcalfe, D.B.; Fisher, R.A.; Wardle, D.A. Plant communities as drivers of soil respiration: Pathways, mechanisms, and significance for global changes. Biogeosciences 2011, 8, 2047-2061. [CrossRef] 
34. Koutika, L.S.; Vanderhoeven, S.; Chapuis-Lardy, L.; Dassonville, N.; Meerts, P. Assessment of changes in soil organic matter after invasion by exotic plant species. Biol. Fertil. Soils 2007, 44, 331-341. [CrossRef]

35. Liao, C.Z.; Peng, R.H.; Luo, Y.Q.; Zhou, X.H.; Wu, X.W.; Fang, C.M.; Chen, J.K.; Li, B. Altered ecosystem carbon and nitrogen cycles by plant invasion: A meta-analysis. New Phytol. 2008, 177, 706-714. [CrossRef] [PubMed]

36. Yang, W.; Yan, Y.; Jiang, F.; Cheng, X.; An, S. Response of the soil microbial community composition and biomass to a short-term Spartina alternifolia invasion in a coastal wetland of eastern China. Plant Soil 2016, 408, 443-456. [CrossRef]

37. Lal, R. Forest soils and carbon sequestration. For. Ecol. Manag. 2005, 220, 242-258. [CrossRef]

38. Driscoll, D.A. Disturbance maintains native and exotic plant species richness in invaded grassy woodlands. J. Veg. Sci. 2017, 28, 573-584. [CrossRef]

39. Stark, J.M.; Firestone, M.K. Mechanisms for soil moisture effects on activity of nitrifying bacteria. Appl. Environ. Microb. 1995, 61, 218-221.

40. Stefanowicz, A.M.; Stanek, M.; Nobis, M.; Zubek, S. Few effects of invasive plants Reynoutria japonica, Rudbeckia laciniata and Solidago gigantea on soil physical and chemical properties. Sci. Total Environ. 2017, 574, 938-946. [CrossRef] [PubMed]

41. Sheahan, C.M.; Bray, D.B.; Bhat, M.G.; Jayachandran, K. Ecological, economic, and organizational dimension of organic farming in Miami-Dade country. J. Sustain. Agric. 2012, 36, 83-105. [CrossRef]

42. Baranová, B.; Fazekašová, D.; Manko, P. Variations of selected soil properties in the grass fields invaded and uninvaded by invasive goldenrod (Solidago canadensis L.). Ekológia Bratisl. 2017, 36, 101-111. [CrossRef]

43. Quist, C.W.; Vervoort, M.T.W.; Van Megen, H.; Gort, G.; Bakker, J.; Van der Putten, W.H.; Helder, J. Selective alteration of soil food web components by invasive giant goldenrod Solidago gigantea in two distinct habitat types. Oikos 2014, 123, 837-845. [CrossRef]

44. Nannipieri, P.; Ascher, J.; Ceccherini, M.T.; Landi, L.; Pietramellara, G.; Renella, G. Microbial diversity and soil functions. Eur. J. Soil Sci. 2003, 54, 655-670. [CrossRef]

45. Chacón, N.; Herrera, I.; Flores, S.; Gonzáles, J.A.; Nassar, J.M. Chemical, physical, and biochemical soil properties and plant roots as affected by native and exotic plants in neotropical arid zones. Biol. Fertil. Soils 2009, 45, 321-328. [CrossRef]

46. Sicardi, M.; Garcìa-Prèchac, F.; Frioni, L. Soil microbial indicators sensitive to land use conversion from pastures to commercial Eucalyptus grandis (Hill ex Maiden) plantations in Uruguay. Appl. Soil Ecol. 2004, 27, 125-133. [CrossRef]

47. Wang, X.; Lu, Q. Beta-glucosidase activity in paddy soils of the Taihu lake region, China. Pedosphere 2006, 16, 118-124. [CrossRef]

48. Kuebbing, S.E.; Classen, A.T.; Simberloff, D. Two co-occurring invasive woody shrubs alter soil properties and promote subdominant invasive species. J. Appl. Ecol. 2014, 51, 124-133. [CrossRef]

49. Sheng, Q.; Zhao, B.; Huang, M.; Wang, L.; Quan, Z.; Fang, C.; Li, B.; Wu, J. Greenhouse gas emission following an invasive eradication program. Ecol. Eng. 2014, 73, 229-237. [CrossRef]

50. Speir, T.W.; Van Schaik, A.P.; Lloyd-Jones, A.R. Temporal response of soil biochemical properties in a pastoral soil alter cultivation following high application rates of undigested sewage sludge. Biol. Fertil. Soils 2003, 38, 377-385. [CrossRef]

51. Corstanaje, R.; Schulin, R.; Lark, R.M. Scale-dependent relationships between soil organic carbon and urease activity. Eur. J. Soil Sci. 2007, 58, 1087-1095. [CrossRef]

52. Ge, Y.; Wang, Q.; Wang, L.; Liu, W.; Liu, X.; Huang, Y.; Christie, P. Response of soil enzymes and microbial communities to root extracts of the alien Alternanthera philoxeroides. Arch. Agron. Soil Sci. 2018, 64, 708-717. [CrossRef]

53. Kourtev, P.S.; Ehrenfeld, J.G.; Häggblom, M. Experimental analysis of the effect of exotic and native plant species on the structure and function of soil microbial communities. Soil Biol. Biochem. 2003, 35, 895-905. [CrossRef] 
54. Bobul'ská, L.; Macková, D.; Malina, R.; Demková, L. Occurrence and dynamics of Impatiens parviflora depending on various environmental conditions in the protected areas in Slovakia. Eur. J. Ecol. 2016, 2, 87-98. [CrossRef]

(․) (1)

(C) 2019 by the authors. Licensee MDPI, Basel, Switzerland. This article is an open access article distributed under the terms and conditions of the Creative Commons Attribution (CC BY) license (http://creativecommons.org/licenses/by/4.0/). 